\title{
Identifikasi Penyebab Penyakit Busuk Pangkal Batang pada Jeruk
}

\author{
Identification of Citrus Basal Stem Rot Disease \\ Eka Retnosari, Julinda Bendalina Dengga Henuk, Meity Suradji Sinaga* \\ Institut Pertanian Bogor, Bogor 16680
}

\begin{abstract}
ABSTRAK
Penyakit busuk pangkal batang (BPB) menjadi kendala utama dan faktor pembatas produksi jeruk nasional. Penelitian bertujuan mengidentifikasi penyebab BPB pada tanaman jeruk dari 11 daerah produksi jeruk di Indonesia. Metode identifikasi patogen dilakukan melalui pengamatan karakter morfologi secara makroskopi dan mikroskopi. Uji Postulat Koch dilakukan untuk meyakinkan penyebab penyakit. Dua jenis patogen, yaitu Botryodiplodia theobromae, dan Phytophthora citrophthora terbukti sebagai penyebab penyakit BPB. B. theobromae ditemukan dari semua sampel tanaman, sedangkan P. citrophthora hanya ditemukan dari sampel tanaman asal Soe (Nusa Tenggara Timur). Uji Postulat Koch membuktikan bahwa dua spesies cendawan tersebut menyebabkan gejala penyakit busuk pangkal batang pada tanaman jeruk yang diinokulasi.
\end{abstract}

Kata kunci: Botryodiplodia theobromae, karakter morfologi, Phytophthora citrophthora, Postulat Koch

\begin{abstract}
One major disease of citrus is basal stem rot which may cause significant constraint on citrus production in Indonesia. Research was initiated to identify the causal agent of basal stem rot disease from 11 citrus growing areas in Indonesia. Identification of fungal pathogens was based on macroscopic and microscopic observation of morphological characters. Koch Postulate was conducted to confirm the causal agent of the disease. Two fungal pathogens, Botryodiplodia theobromae, and Phytophthora citrophthora were found associated with basal stem rot disease. B. theobromaewere isolated from all plant samples, whereas P. citrophthorawas only isolated on samples from Soe (East Nusa Tenggara). Characteristic symptoms of basal stem rot disease was developed on plants inoculated with $B$. theobromae and $P$. citrophthora; this confirmed that two fungal isolates was the causal agent of basal stem rot disease.
\end{abstract}

Key words: Botryodiplodia theobromae, Koch postulate, morphological character, Phytophthora citrophthora

\section{PENDAHULUAN}

Jeruk merupakan salah satu komoditas hortikultura penting dan bernilai ekonomi tinggi. Salah satu kendala utama produksi jeruk ialah gangguan hama dan penyakit.
Sejak tahun 1970 kondisi pertanaman jeruk di Indonesia mengalami degradasi dan hampir mengalami kehancuran karena terserang penyakit yang sangat membahayakan, yaitu penyakit citrus vein phloem degeneration (CVPD) dan Tristeza. Penyakit CVPD

*Alamat penulis korespondensi: Departemen Proteksi Tanaman, Fakultas Pertanian, Institut Pertanian Bogor Jalan Kamper, Kampus Darmaga IPB, Bogor 16680

Tel: 0251-8629364,Faks: 0251-8629362, Surel: mssinaga@yahoo.com 
dilaporkan menyebar secara luas di Indonesia dan menyebabkan penurunan produksi jeruk (Taufik et al. 2010).

Akhir-akhir ini dilaporkan adanya insidensi penyakit busuk pangkal batang (BPB) di beberapa sentra penanaman jeruk di Indonesia. Penyakit BPB atau disebut juga penyakit blendok menyebar sangat cepat dan dapat menyebabkan kematian tanaman saat masih di pembibitan maupun tanaman yang sudah berproduksi di lapangan. Tanaman jeruk yang terserang menunjukkan gejala busuk pada pangkal batang disertai terbentuknya "blendok" (gumosis) dan mengeluarkan aroma asam (Verniere et al. 2004). Savita et al. (2012) melaporkan bahwa Phytophthora parasitica (P. nicotianae), P. palmivora, dan $P$. citrophthora merupakan spesies penting yang menginfeksi jeruk.

Gejala mirip busuk pangkal batang juga sering ditemukan pada tanaman jeruk di Indonesia. Penyakit kulit batang yang disebabkan oleh Botryodiplodia spp. menyebabkan gejala berupa blendok berwarna kuning yang keluar dari batang atau cabang-cabang besar. Kulit batang yang sakit akan terkelupas, penyakit terus berkembang sehingga pada kulit batang terjadi luka yang tidak teratur, meluas tetapi dangkal. Umumnya infeksi baru diketahui jika daun-daun telah menguning sehingga batang atau cabang yang sakit sudah mengalami kematian (Sado et al. 2008; Gusnawaty dan Mariadi 2013)

Sampai saat ini belum ada identifikasi yang tepat mengenai patogen utama BPB di sentra produksi jeruk di Indonesia. Oleh karena itu, penelitian dilakukan untuk mengidentifikasi penyebab BPB jeruk dengan metode konvensional berdasarkan karakter morfologi cendawan patogen. Identifikasi penyebab penyakit yang akurat sangat diperlukan sebagai dasar menyusun strategi pengendalian penyakit yang efektif dan efisien.

\section{BAHAN DAN METODE}

\section{Sampel Tanaman Sakit}

Pengumpulan bahan tanaman sakit dilakukan dari 11 daerah sentra produksi jeruk yang ada di Indonesia, yaitu Garut (Jawa Barat), Jember dan Malang (Jawa Timur), Kintamani (Bali), Soe (Nusa Tenggara Timur), Banjarmasin dan Banjarbaru (Kalimantan Selatan), Berastagi (Sumatera Utara), Kampar (Riau), Muara Jambi (Jambi), dan Tulang Bawang Barat (Lampung). Bahan tanaman sakit berupa batang jeruk yang menunjukkan gejala serta tanah di sekitar pertanaman jeruk yang terserang.

\section{Isolasi Patogen dari Bahan Tanaman Sakit}

Isolasi dari batang dilakukan dengan metode penanaman jaringan. Sampel batang dicuci dengan air mengalir, kemudian dipotong dan didesinfeksi dengan merendamnya dalam kloroks $0.5 \%$ selama satu menit. Potongan batang dibilas menggunakan air steril sebanyak tiga kali, kemudian ditanam pada medium agar-agar kentang dekstrosa (ADK). Koloni isolat cendawan yang tumbuh dan menunjukkan ciri koloni Phytophthora spp. dibiakkan pada medium agar-agar V8 untuk merangsang sporulasinya .

Isolasi sampel tanah dilakukan dengan metode pengumpanan buah apel. Pengumpanan dilakukan dengan cara melubangi buah apel dengan pembor gabus sedalam $\pm 1 \mathrm{~cm}$, sebelumnya buah apel diberi perlakuan desinfeksi dengan $\mathrm{NaOCl}$ 1\%. Sampel tanah dimasukkan ke dalam lubang pada buah apel, kemudian lubang ditutup dengan selotip, dan diinkubasi selama 2-3 hari pada suhu ruang. Jika terlihat gejala bercak yang muncul pada buah, bagian yang bergejala tersebut diambil dan dibiakkan pada medium ADK dan medium selektif agar-agar V8.

\section{Identifikasi Patogen Berdasarkan Karakter Morfologi}

Identifikasi patogen secara makroskopi dilakukan dengan mengamati warna koloni, tipe koloni, dan lama pertumbuhan cendawan pada medium ADK dan agar-agar V8. Identifikasi secara mikroskopi dilakukan untuk menentukan karakter morfologi Phytophthora yang meliputi bentuk dan ukuran sporangium, sporangiofor, papila, septum hifa, dan klamidospora. Karakter 
morfologi Botryodiplodia atau Diplodia yang diamati meliputi hifa, stroma, piknidium, konidiofor, klamidospora, bentuk dan ukuran konidium. Kunci identifikasi Phytophthora menggunakan Erwin dan Ribeiro (1996) dan Botryodiplodia menggunakan Barnett dan Hunter (1998).

\section{Uji Postulat Koch}

Uji ini dilakukan menggunakan batang planlet dan bibit jeruk varietas Japanese citroen. Batang disemprot dengan air steril, dibersihkan menggunakan kloroks $0.5 \%$, dan dibilas dengan air steril. Permukaan batang dilukai dengan jarum sebanyak 5 kali tusukan. Potongan biakan murni patogen berumur 6 hari ditempelkan pada bagian luka tersebut, kemudian ditutup dengan kapas yang dibasahi air steril dan diselotip. Insidensi penyakit ditentukan berdasarkan gejala yang muncul.

\section{HASIL}

\section{Penyebab Penyakit}

Botryodiplodia spp. ditemukan dari semua sampel tanaman sakit, sedangkan Phytophthora spp. hanya ditemukan dari sampel asal Kabupaten Soe, Nusa Tenggara Timur.

Koloni Botryodiplodia spp. awalnya berwarna putih dan pertumbuhannya aerial, namun setelah hari ke-4 miselium menjadi abu-abu sampai kehitaman dan setelah 7 atau
8 hari menjadi berwarna hitam. Secara umum pertumbuhan Botryodiplodia spp. sangat cepat pada medium ADK. Hifa Botryodiplodia spp. bersekat, hialin dan menjadi kecokelatan sejalan umur. Pembentukan klamidospora secara interkalar. Pertumbuhan piknidium pada medium ADK sangat lambat, yaitu \pm 30 hari setelah isolasi. Ketika koloninya dipindahkan ke medium agar-agar air yang diberi potongan jerami padi steril maka piknidium dibentuk pada hari ke-14. Pembentukan piknidium terjadi secara berkelompok dalam stroma. Piknidium berisi banyak konidium muda dan konidium matang, keduanya berbentuk ovoid dan elipsoid. Konidium muda berwarna hialin, dindingnya terdiri atas dua lapisan, berbentuk granular dan tidak bersekat. Konidium matang berwarna cokelat, dinding selnya hanya satu lapisan dan memiliki satu sekat sehingga membentuk dua sel. Ukuran konidium bervariasi dengan panjang 18.8 $31.9 \mu \mathrm{m}$ dan lebar 11.3-18.8 $\mu \mathrm{m}$ (Tabel 1). Berdasarkan karakter morfologi yang diamati secara mikroskopi, isolat tersebut merupakan B. theobromae.

Koloni Phytophthora spp. yang dibiakkan pada medium ADK dapat tumbuh memenuhi cawan berdiameter $9 \mathrm{~cm}$ pada 12 hari setelah inokulasi; sedangkan pada medium agaragar V8 pertumbuhan koloni lebih cepat, yaitu 10 hari setelah inokulasi. Hifa tidak bersekat, bercabang, hialin, terdapat bagian yang membengkak. Klamidospora membulat

Tabel 1 Ukuran konidium Botryodiplodia theobromae

\begin{tabular}{lcccc}
\hline Asal isolat & $\begin{array}{c}\text { Panjang }(\mathrm{p}) \\
(\mu \mathrm{m})\end{array}$ & $\begin{array}{c}\text { Lebar }(\mathrm{l}) \\
(\mu \mathrm{m})\end{array}$ & $\begin{array}{c}\text { Rata-rata } \mathrm{p} \times \mathrm{l} \\
(\mu \mathrm{m})\end{array}$ & \begin{tabular}{c} 
Nisbah $\mathrm{p}: 1$ \\
\hline Berastagi
\end{tabular} \\
Kampar & $26.3-30.0$ & $13.1-15.0$ & $27.8 \times 14.3$ & 2.0 \\
Muara Jambi & $26.3-28.1$ & $13.1-16.9$ & $27.4 \times 14.6$ & 1.9 \\
Tulang Bawang Barat & $24.4-28.1$ & $13.1-16.9$ & $26.3 \times 15.0$ & 1.8 \\
Garut & $24.4-28.1$ & $15.0-16.9$ & $26.3 \times 15.4$ & 1.7 \\
Jember & $26.3-30.0$ & $15.0-16.9$ & $27.8 \times 16.1$ & 1.7 \\
Malang & $28.1-30.0$ & $15.0-18.8$ & $28.5 \times 16.9$ & 1.7 \\
Kintamani & $22.5-26.3$ & $13.1-15.0$ & $24.8 \times 14.3$ & 1.7 \\
Soe & $18.8-24.4$ & $11.3-15.0$ & $21.8 \times 13.1$ & 1.7 \\
Banjarbaru & $18.8-26.3$ & 11.3 & $22.5 \times 11.3$ & 2.0 \\
Banjarmasin & $24.4-26.3$ & 15.0 & $25.5 \times 15.0$ & 1.7 \\
\hline
\end{tabular}


dibentuk secara interkalar. Bentuk sporangium tidak beraturan atau asimetris, dapat dibedakan menjadi 3 jenis (Gambar 1). Sporangium tipe c berukuran lebih besar dibandingkan dengan sporangium tipe a dan $\mathrm{b}$ (Tabel 2). Berdasarkan kunci identifikasi Erwin dan Ribeiro (1996), isolat Phytophthora spp. yang berasal dari Kabupaten Soe (NTT) ialah P. citrophthora.

\section{Uji Postulat Koch}

Pada tanaman kontrol tidak terlihat munculnya gejala, sedangkan tanaman yang diinokulasi menunjukkan gejala berupa nekrosis pada titik inokulasi setelah permukaan batang disayat. Planlet Japanese citroen yang diinokulasi menunjukkan gejala klorosis yang berkembang menjadi nekrotik dan membentuk gumosis, akhirnya mengalami kematian. Perkembangan pertumbuhan dan infeksi $B$. theobromae lebih cepat dibandingkan dengan $P$. cithrophthora meskipun gejala awal berupa klorosis terbentuk pada waktu yang sama, yaitu 3 hari setelah inokulasi. Gejala pada bibit berupa gejala cekung pada permukaan kulit batang dan mengeluarkan gumosis yang terlihat bening ketika basah dan menjadi cokelat keemasan setelah mengering. Bercak meluas sampai mengelilingi batang dan akar membusuk sehingga bibit mengalami kematian.

\section{PEMBAHASAN}

Penyakit BPB yang menyerang tanaman jeruk tersebar di seluruh dunia dan menyebabkan kehilangan hasil. Penyakit tersebut menyebabkan daun, bunga, dan buah mengering dan rontok pada semua stadium pertumbuhan tanaman di pembibitan maupun di lapangan. Gejala khas penyakit BPB berupa busuk pada batang bawah atau di sekitar mahkota akar dekat dengan permukaan tanah. Busuk batang ditandai oleh jaringan batang dan kambium berwarna cokelat kekuningan. Pada permukaan batang, infeksi sering tampak seperti terlokalisasi atau sering kelihatan tidak meluas walaupun sebenarnya infeksi sudah meluas pada kambium dan menyebabkan jaringan batang retak, hancur dan mengeluarkan gumosis. Pada batang di atas permukaan tanah, gumosis dapat terjadi berlebihan, sedangkan di bawah permukaan tanah pembentukan gumosis berkurang karena biasanya terserap oleh air tanah (Savita et al. 2012).

Pengendalian penyakit BPB terutama dilakukan secara kultur teknis dan kimiawi. Efisiensi pestisida nabati dari kulit biji mete untuk menekan penyakit kulit diplodia telah diteliti Gusnawaty dan Mariadi (2013). Pengendalian secara kultur teknis yang

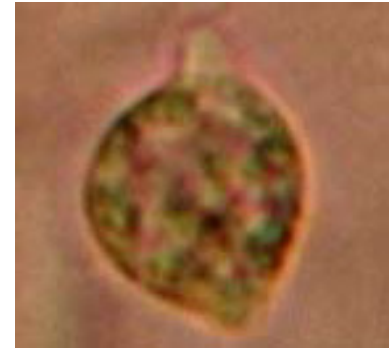

a

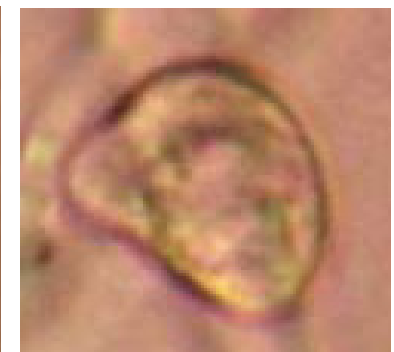

b

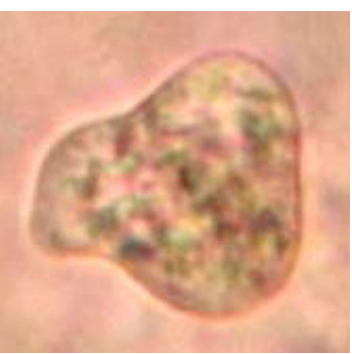

C

Gambar 1 Bentuk asimetri sporangium Phytophthora citrophthora.

Tabel 2 Ukuran sporangium Phytophthora citrophthora

\begin{tabular}{ccccc}
\hline $\begin{array}{l}\text { Tipe } \\
\text { sporangium* }\end{array}$ & $\begin{array}{c}\text { Panjang }(\mathrm{p}) \\
(\mu \mathrm{m})\end{array}$ & $\begin{array}{c}\text { Lebar }(1) \\
(\mu \mathrm{m})\end{array}$ & $\begin{array}{c}\text { Rata-rata } \mathrm{p} \times 1 \\
(\mu \mathrm{m})\end{array}$ & Nisbah $\mathrm{p}: 1$ \\
\hline $\mathrm{a}$ & $14.2-19.3$ & $11.3-16.9$ & $18.8 \times 15.0$ & 1.3 \\
$\mathrm{~b}$ & $11.3-16.9$ & $9.1-14.2$ & $15.0 \times 13.1$ & 1.1 \\
$\mathrm{c}$ & $24.4-28.1$ & $14.2-19.3$ & $26.3 \times 18.8$ & 1.4 \\
\hline
\end{tabular}

* Bentuk sporangium P. citrophthora ialah asimetris (distorsi). 
dianjurkan ialah melalui penanaman jeruk di atas gundukan-gundukan setinggi 20$25 \mathrm{~cm}$, tetapi tanaman tidak dibumbun agar batang atas tidak berhubungan dengan tanah. Benih disarankan menggunakan mata tempel setinggi 30-35 cm dari permukaan tanah untuk mengurangi kemungkinan batang atas yang rentan terinfeksi cendawan tanah. Selama pertumbuhan tanaman harus diupayakan untuk mengurangi kelembapan kebun dan mengatur drainase, memperhatikan sanitasi lingkungan atau kebun. Pelukaan pada akar dan pangkal batang harus dihindari. Apabila ditemui gejala tanaman yang terserang berat harus segera dibongkar dan dibakar. Demikian pula, bagian tanaman yang menunjukkan gejala awal harus dipotong dan dibakar. Setelah dipotong, bagian kulit batang yang sehat di sekitarnya diolesi fungisida karbendazim $6.2 \%$ ditambah dengan mankozeb atau tembaga oksiklorida $73.8 \%$. Tindakan pencegahan penyakit secara kimiawi umumnya dilakukan dengan pengolesan ter (Carbolineum plantarum 50\%) pada pangkal batang dan akar-akar yang tampak dari luar sampai setinggi $50 \mathrm{~cm}$. Perlakuan tersebut dianjurkan dimulai pada tahun ketiga setelah penanaman dan setiap awal musim hujan (Alvarez et al. 2008; Savita et al. 2012).

Hasil identifikasi cendawan membuktikan bahwa $B$. theobromae merupakan patogen penyebab penyakit BPB di 11 daerah (Garut, Jember, Malang, Kintamani, Soe, Banjarmasin, Banjarbaru, Berastagi, Kampar, Muara Jambi, dan Tulang Bawang Barat) serta P. citrophthora di daerah Soe (Nusa Tenggara Timur. Dari daerah Banjarmasin juga diperoleh isolat Gliocladium sp., tetapi isolat tersebut terbukti bukan penyebab penyakit BPB. Hasil ini merupakan konfirmasi bahwa penyebab utama BPB pada jeruk di Indonesia ialah $B$. theobromae.

\section{DAFTAR PUSTAKA}

Alvarez LA, Vincent A, De la Reca E, Bascon J, Abad-Campos P, Aremongal J. 2008. Branch cankers on citrus tress in Spain caused by Phytophthora citrophthora. Plant Pathol. 57(1):84-91. DOI: http://dx.doi. org/10.1111/j.1365-3059.2007.01702.x.

BarnettHL, Hunter BB. 1998. Ilustrated Genera of Imperfect Fungi. Ed ke-4.Minnesota (US): Burgess Publishing Company. Erwin DC, Ribeiro OK. 1996. Phytophthora Diseases Worldwide. Minnesota (US): APS Press.

Gusnawaty HS, Mariadi. 2013. Pengendalian penyakit diplodia (Botryodiplodia theobromae Pat.) pada tanaman jeruk dengan pestisida nabati (Phymar C) di Sulawesi Tenggara. Agriplus. 23(2):98102.

Sado F, Yumi I, Keisuke T, Satoshi T, Atsushio, Kazuko T. 2008. Black band of jew's marrow caused by Lasiodiplodia theobromae. J Gen Plant Pathol. 74:91-93. DOI: http://dx.doi.org/10.1007/s10327-00 7-0056-2.

Savita, Virk GS, Nagpal A. 2012. Citrus diseases caused by Phytophthora species. GERF Bull Biosci. 3(1):18-27.

Taufik M, Kharuni A, Pakki T, Giyanto. 2010. Deteksi keberadaan citrus vein phloem degeneration (CVPD) dengan teknik polymerase chain reaction (PCR) di Sulawesi Tenggara. J HPT Tropika. 10(1):73-79.

Verniere C, Cohen S, Raffanel B, Dubois A, Venars P, Panabieres F. 2004. Variability in pathogenicity among Phytophthora spp. isolated from citrus disease in Corsica. J Phytopathol. 152(8-9):476-483. DOI: http://dx.doi.org/10.1111/j.1439-0434. 2004.00878.x. 